\title{
Social Aspects of Energy Production from Renewable Sources
}

\section{Społeczne aspekty produkcji energii ze źródeł odnawialnych}

\section{Wojciech Czekała*, Filip Tarkowski**, Patrycja Pochwatka***}

\author{
*-Department of Biosystems Engineering, Poznań University of Life Sciences, \\ Wojska Polskiego 50, 60-627 Poznań, Poland \\ E-mail (Corresponding Author): wojciech.czekala@up.poznan.pl \\ ORCID: 0000-0002-7750-9265, SCOPUS Author ID: 55956882400 \\ **Department of Biosystems Engineering, Poznań University of Life Sciences, Students \\ Scientific Association of Ecoenergy, Wojska Polskiego 50, 60-627 Poznań, Poland \\ ***Department of Environmental Engineering and Geodesy, University of Life Sciences in \\ Lublin, Leszczyńskiego 7, 20-069 Lublin, Poland
}

\begin{abstract}
The increased demand for energy determines the need to search for its next sources. One of them could be renewable energy sources, whose importance is increasing, among others, due to the limited resources of fossil fuels. In addition, renewable energy production has many benefits, mainly environmental and economic. Moreover, the social aspects associated with it cannot be ignored. The aim of this work was to discuss selected social benefits resulting from the production of renewable energy.

Among the most important advantages of renewable energy sources is their local aspect, since energy production solves many regional problems, mainly related to its transport. The issue of energy security is also essential. In the case of biofuel production, the possibility of involving waste in energy production is extremely beneficial. The use of renewable energy itself directly affects the improvement of the environment, which in turn has a positive effect on people.

Nowadays, sustainable development is one of the most critical challenges of humanity. These activities are closely related to the use of renewable energy sources. It is important to pay attention not only to subjects related to the environmental and economic aspects but also the impact of renewable energy sources on society.
\end{abstract}

Key words: renewable energy sources, sustainable development, circular economy, social aspects, energy production

\begin{abstract}
Streszczenie
Zwiększone zapotrzebowanie na energię warunkuje konieczność poszukiwania jej kolejnych źródeł. Jednym z nich mogą być odnawialne źródła energii, których znaczenie jest coraz większe, między innymi za sprawą ograniczonych zasobów paliw kopalnych. Poza tym produkcja energii z OZE niesie za sobą wiele korzyści, głównie środowiskowych oraz ekonomicznych. Nie można pominąć również aspektów społecznych z nią związanych. Celem pracy było omówienie wybranych korzyści społecznych, wynikających z produkcji energii odnawialnej. Wśród najważniejszych zalet OZE wymienia się ich lokalny aspekt, w związku z tym, że produkcja energii rozwiązuje wiele problemów lokalnych, związanych głównie z przesyłem. Ważny jest również aspekt bezpieczeństwa energetycznego. W przypadku produkcji biopaliw niezwykle korzystna jest możliwość zagospodarowania odpadów do produkcji energii. Samo wykorzystanie OZE bezpośrednio oddziałuje na polepszenie stanu środowiska, co w konsekwencji pozytywnie wpływa na ludzi.

W obecnych czasach zrównoważony rozwój jest jednym z najważniejszych wyzwań ludzkości. Działania te są ściśle związane z wykorzystaniem odnawialnych źródeł energii. Ważnym jest, aby obok aspektów środowiskowych i ekonomicznych zwracać również uwagę na tematy związane z wpływem OZE na społeczeństwo.
\end{abstract}

Słowa kluczowe: odnawialne źródła energii, zrównoważony rozwój, gospodarka o obiegu zamkniętym, aspekty społeczne, produkcja energii 


\section{Introduction}

The systematic development of industry and technology has led to the improvement of the societies standard of living in most countries of the world. This progress is closely related to the availability of raw materials used for production and energy purposes (Chow, 2003). Raw materials, especially fossil fuels, condition the development of the world economy, which leads to a quantitative increase in their extraction (Ritchie, 2020). According to a UN report, by 2050 , the world population could rise to 9.7 billion (United Nations, 2019). These data, together with the systematic development of technology, confirm the thesis that the growing tendency of energy demand will continue or even increase (Edenhofer, 2012). Thus, actions are already being taken to meet the demand for energy. The indicator expressing the ratio of raw material resources to the level of production for a given type of fuel determines the probable lifetime of a given resource. Based on this indicator and the rate of variable gas and oil production in 2018, it has been assumed that in about 50 years, these resources will be exhausted. In the case of hard coal, by using the above indicator, it was expected that the amount of available resources would be enough for the next 132 years (BP, 2019).

The extraction and processing of fossil fuels have an impact on environmental degradation, which is expressed in economic and environmental aspects. This, in turn, also negatively affects the quality of human life (Union of Concerned Scientises, 2016). It is estimated that in 2017, weather-related disasters caused a record $€ 283$ billion in economic damages (European Commission, 2018). Damages caused at the level of the natural environment, like drought, hurricanes, fires, and the prospect of their intensification in the coming years, are also disturbing. Research published in 2019 (European Commission, 2017) shows that $92 \%$ of Europeans consider climate change a serious problem. All this leads to the need to run an economy based on the principles of sustainable development, where the crucial aspect is the vision of a stable future.

In 2017, the estimated share of renewable sources in global final energy consumption was around $18.1 \%$ (Renewables, 2019). Social studies show that $89 \%$ of Europeans think that one of the directions for Europe's development should be maximizing energy production from renewable sources (European Commission, 2017). It is supported by the fact that the production of energy from renewable sources, unlike other methods, is associated with only a limited level of greenhouse gas emissions. Besides, under renewable energy conditions, direct interference with the natural environment, mainly related to the construction of installations of a renewable nature and compared to the mining industry, is significantly less invasive (Akella, 2009).
In answer to factors mentioned above and others prompt moving towards sustainable development, the EU has established a set of targets concerning a transition to a low-carbon, climate-neutral, resourceefficient, and biodiverse economy. The way to reach ambitions aims is to reducing dependence on nonrenewable resources and maximize the use of sustainably managed renewable resources (European Commission, 2019). Moreover, one of the goals of the sustainable development of the UN 2030 Agenda is to ensure universal access to affordable and clean energy. Among the tasks set for 2030 can be mentioned: significantly increasing the share of renewable energy sources in the global energy mix, double the growth rate of global energy efficiency, and increase an international cooperation to facilitate access to clean energy research and technologies in the field of renewable energy, energy efficiency, and advanced and cleaner fossil fuel technologies, and promote investing in energy infrastructure and clean energy technologies (McCollum, 2017).

Certainly, the development of renewable energy only will not solve the problem of the greenhouse effect, environmental degradation, or improvement of the quality of life of the entire population of people in the world. Still, it will surely help reduce numerous, generally negative problems. In addition to environmental and economic aspects, more and more attention should also be paid to social issues. The aim of this work was to discuss selected social benefits resulting from the production of renewable energy.

\section{Society benefits of energy production from ren- wable sources}

Scientific research and the general belief emphasize the need to develop the economy in a sustainable manner, which is closely related to the use of renewable energy sources (Dincer, 2000). Thus, the economy based so far predominantly on fossil fuels should be rebuilt into one in which renewable sources will dominate. This process can eliminate the extraction of fossil fuels completely, but it is necessary to reduce their share in global energy production systematically. The goal of future technology should be to maintain the continuity of civilization development, considering the minimization of environmental damage.

Realization of this goal requires changes not only at the global or national level, but also changes and acceptance by every citizen, especially because the level of human consumption has an impact on the state of the natural environment (Shwom, 2012). A significant change in human energy management and mentality is necessary because it brings several benefits, e.g., in terms of its impact on society (Pawłowski, 2012).

The extraction and combustion of fossil fuels is an important factor in greenhouse gas emissions 
(Edenhofer, 2012). The effects of global warming, especially the increase in the average temperature on Earth, may, in the future, affect many aspects, negatively affect the standard of living of many organisms, including humans (Kerr, 2007). These effects caused by, among others, conventional energy significantly disturb the global ecosystem, which is a key aspect of the life of all organisms (Chapin III, 2000).

Emissions of pollutants associated with the mining industry and fuel combustion also have a direct negative impact on life, which is manifested in a strong correlation between the level of air pollution and the number of deaths (Schwartz, 1990). EU regulations and modern solutions implementation have resulted in emitted pollution reduction and improved air quality (Kuklinska, 2015). However, in many European cities, air pollution still poses a danger to human health and the environment. It is estimated that air pollution concentrations in 2016 contributed to 374 000 premature deaths in the EU (EEA Report, 2019). Current air pollution quality standards for particulate matter (PM) use the PM mass concentration. According to research, PM2.5 are pollutants widely regarded as the most harmful to human health. PM2.5 rate above $12.0\left(\mu \mathrm{g} / \mathrm{m}^{3}\right)$ may have a negative impact on health (IQAir, 2019). The target of the World Health Organization is to maintain a PM2.5 rate under $10.0\left(\mu \mathrm{g} / \mathrm{m}^{3}\right)$. The diagram below presents the annual mean PM2.5 level in European countries in 2019 (Fig. 1.) (IQ Air, 2019). It should be noted, however, that those high concentrations of PM2.5 concern mainly cities. According to the report mentioned above, five out of ten most polluted cities were Turkish, four out of ten were located in Bosnia and Herzegovina, and one was Serbian city.

Primary air pollution sources are fuel combustion from road transport, households to energy use and production. Reducing the share of conventional sources in the global energy economy in favor of low-carbon renewable energy sources will help improve air quality and reduce harmful greenhouse gas emissions (Alvarez-Herranz, 2017), (Panwar, 2011). Actions taken to reduce these emissions would have far-reaching benefits, including improving the quality of life for future generations.

Construction of a power station based on fossil fuels is associated with environmental degradation, often with deforestation of its origin and nearby areas. Thus, the fossil fuel industry has a direct negative impact on species biodiversity (Butt, 2013), which is a significant aspect in the dimension of human existence, including in the context of food chain continuity and nature aesthetics. Besides, actions that reduce the population of plants conducting photosynthesis deepen the effect of high concentrations of $\mathrm{CO}_{2}$ and other greenhouse gases in the atmosphere. In this context, the specificity of installations enabling the acquisition of energy from renewable sources is sig- nificantly less invasive for the environment. An increase in the renewable energy share would also reduce the need to destroy green areas to build energy installations. Such actions would contribute to maintaining the biosphere, which has a positive effect on many levels.

Another positive feature of renewable energy sources is their public accessibility, and the fact that a large part of various types of installations necessary for the production of renewable energy does not require transport of the raw material. This is another aspect encouraging the development of this energy sector. In the case of biomass-based power stations, the widespread availability of raw material means that the transport takes place over shorter distances than in the case of spot fossil fuels. In turn, results in reduced exhaust emissions and a reduction in the negative impact that transport has on the environment. An additional advantage worth emphasizing is the fact that many farmers and crop processing plants can become suppliers of substrates for a biofuel station. Such action will bring mutual benefits.

Due to the increase in fuel extraction costs and the depletion of their resources, the rationality of energy production from renewable sources will take on economic profitability. The mining industry is associated with very large financial outlays related to the construction of power stations, extraction of raw material, and appropriate adaptation of infrastructure. An increase in the use of inexhaustible and readily available energy sources as an alternative to fossil fuels would have a beneficial effect on reducing electricity prices (Krozer, 2013).

Given the world's regions and the differences between them, one must bear in mind the fact that there are differences in the possibilities, efficiency, and economic profitability of producing energy from renewable sources. However, this production is and will be less dependent on geographical conditions compared to fossil fuels. In turn, it has a positive impact on the economy and energy security of the country as well as smaller areas.

As mentioned earlier, the location of installations to produce energy from renewable sources is less dependent on geographical conditions than the case with fossil fuels. This aspect favors the decentralization of the energy economy and increases energy security. The expansion of a decentralized energy system based on renewable energy sources could significantly increase the standard of living of people in regions of the world where there is a problem in the supply of electricity, providing greater security (Zahnd, 2009). This is particularly important for poorer countries that do not have their own fossil fuel resources or sufficient funds to build power stations. Therefore, investment in publicly available renewable sources is a chance for these countries, especially since the decentralized system also results in a reduction of costs related to energy transfer. 


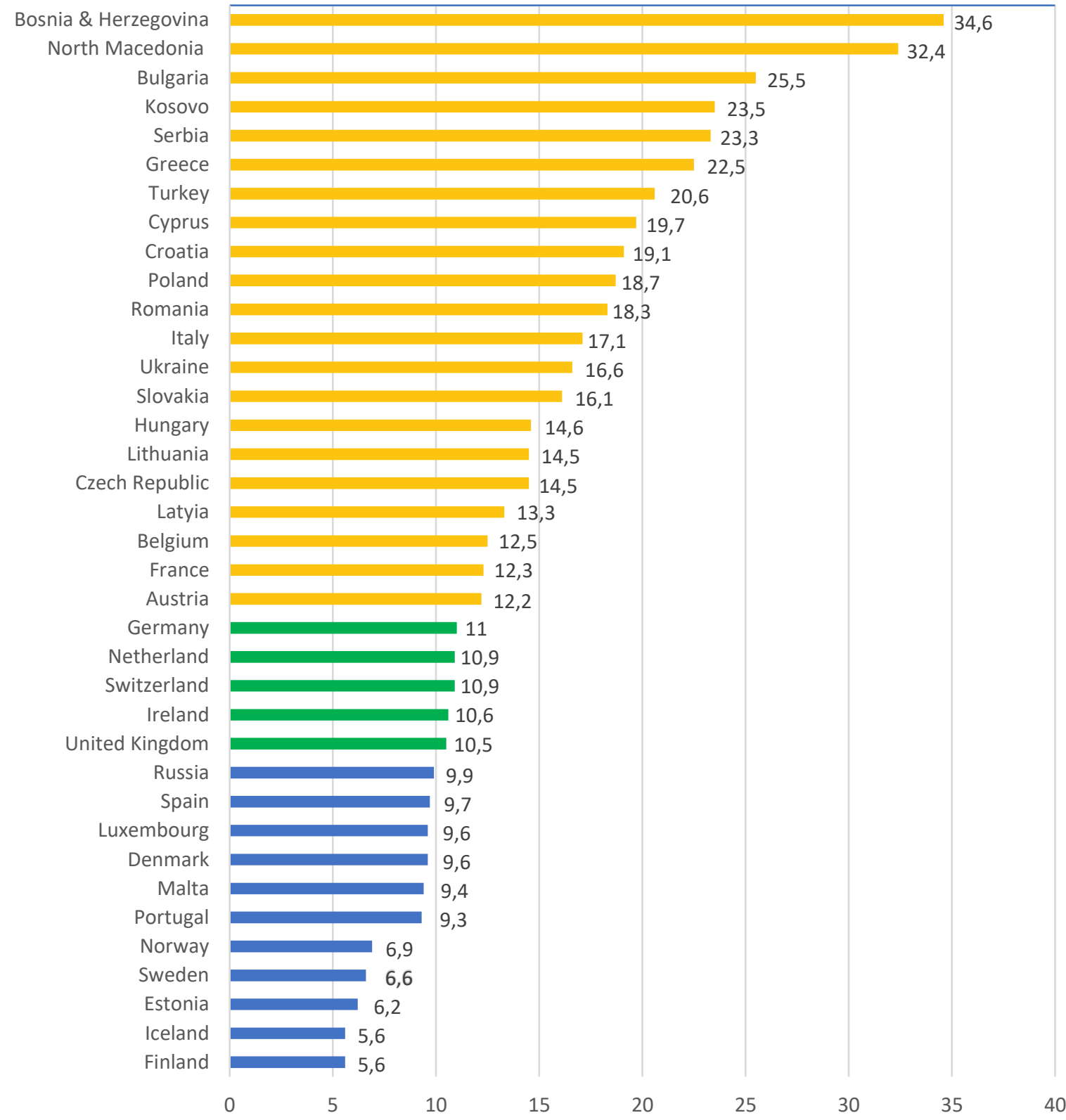

Figure 1. Annual mean PM2.5 level in European countries in 2019 (PM2.5) [ $\left.\mu \mathrm{g} / \mathrm{m}^{3}\right]$, (IQ Air, 2019).

Decentralizing energy management allows reducing the distance over which electricity is transmitted, and the production of energy close to where it is consumed would, in turn, improve network voltage, reduce system losses and reduce power shortages (Akella, 2009). This solution increases the security of a continuous power supply. In addition, research indicates that the use of a decentralized renewable energy system in rural regions can be cheaper than using electricity from a network source (Silva Herran, 2012), (Nguyen, 2007).

An example of decentralized energy sources is prosumer solar installations, which are becoming increasingly widespread in the EU. Prosumer installa- tions with high potential, however, require an appropriate economic policy. This is necessary for the profitability of the investment, which would encourage society to install them. Considering the installation's current prices and energy efficiency, longterm investment in photovoltaic installations provides significant savings in terms of electricity costs. Also, the prosumer is less exposed to a possible increase in energy prices.

Decentralization of the energy source would create new jobs, boosting economic growth. It will be the result of investments made in this area and human work necessary for their implementation. The expansion of the renewable energy sector would also trig- 
ger capital trading. Investments related to the decentralization of energy require the involvement of many separate economic sectors, providing each of them with the benefits of services. In turn, renewable sources' availability allows the implementation of investments also in less urbanized areas, which allows powering the local economy quite evenly in many different regions. According to estimates, the transition to a global power system, fully based on renewable energy sources, would create 17 million new job places compared to 2015 (Ram, 2017).

Waste can be used to produce biofuels that are an energy carrier. The process of obtaining biogas enables the management of surplus agricultural waste and manure at the local level. Biogas production also brings environmental benefits. It contributes to the reduction of greenhouse gases and allows the management of materials whose surplus harms the natural environment (Pei-dong, 2007). For example, excessive fertilization and animal manure storage can be degrading to the quality of nearby soils and groundwater (Holm-Nielsen, 2009). In addition, the methane fermentation process contributes to the reduction in the digestate substance of the number of pathogenic bacteria from the genus Salmonella, and digestate, which is a residue of methane fermentation, can be used as a fertilizer (Makara, 2017).

The natural environment and its condition also have a significant positive impact on society on the psychological level (Mantler, 2015). Thus, social aspects often correlate with environmental elements. According to the research, being surrounded by nature reduces the level of stress. It is commonly believed that even a short time spent surrounded by nature improves the mood and creates a sense of peace. Renewable energy sources certainly improve the aesthetic effect, especially in the context of places such as mines. The above-mentioned, multifaceted benefits motivate to take actions to protect the environment and build a sustainable economy. Renewable energy sources, commonly called green energy, thanks to their specificity, can be a key tool to achieve these goals. According to analyzes, the change in the source of energy production on Earth will have a positive impact on many levels of human existence, and the need to reduce the negative impact on the state of the environment is also confirmed by the premises resulting from human reflection.

\section{Conclusion}

The vision of an economy based solely or largely on fossil fuels has some disadvantages. They are mainly associated with environmental degradation and shrinking fuel resources. The development of industry and mass extraction of raw materials, including energy, is considered by many to be the main causes of climate change, which may have catastrophic consequences in the future.
The sustainable development of the energy sector is justified not only in environmental and economic aspects but also in terms of its impact on society. These activities show that there is widespread opposition to the negative impact on the environment. Renewable energy sources can be a suitable replacement for conventional fuels, improving the quality of life, and allowing a positive view of planet Earth's future.

\section{Acknowledgements}

This study was performed as part of the statutory research no. 506.105.06.00 in the discipline of Environmental Engineering, Mining and Energetics, entitled Energetic use of waste as a method of improving the environment.

\section{References}

1. AKElla A. K., SAINI R. P., SHARAMA M. P., 2009, Social, economic and environmental impacts of renewable energy systems, in: Renewable Energy, 34(2), p. 390-396.

2. ALVAREZ- HERRANZ A., BALSALOBRELORENTE D., SHAHBAZ M., CANTOS J. M., 2017, Energy innovation and renewable energy consumption in the correction of air pollution, in: Energy Policy, 105, p. 386-397.

3. BP, 2019, BP Statistical Review of World Energy, $68^{\text {th }}$ edition, London.

4. BUTT N., BEYER H. L., BENNETT J. R., et al., 2013, Biodiversity Risks from Fossil Fuel Extraction, in: Science, 342(6157), p. 425-426.

5. CHAPIN III F., ZAVALETA E. S., EVINER V. T., et al., 2000, Consequences of changing biodiversity, in: Nature, 405, p. 234-242.

6. CHOW J., KOPP R., PORTNEY P., 2003, Energy Resources and Global Development, in: Science, 302, p. $1528-1531$.

7. DINCER I., 2000, Dhahran, Renewable energy and sustainable development: a crucial review, in: Renewable \& Sustainable Energy Reviews, 4, p. 157- 175.

8. EDENHOFER O., MADRUGA R. P. et al., 2012, Renewable Energy Sources and Climate Change Mitigation, Special Report of the Intergovernmental Panel on Climate Change, (IPCC), New York.

9. European Commission, 2017, Climate Change Raport, Special Eurobarometer 459.

10. European Commission, 2018, European strategic long-term vision for a prosperous, modern, competitive and climate neutral economy, Brussels.

11. European Commission, 2019, Towards a sustainable Europe by 2030.

12. European Environment Agency, 2019, Air quality in Europe - 2019 report.

13. HOLM-NIELSEN J.B., AL SEADI T., OLESKOWICZ-POPIEL P., 2009, The future of anaerobic digestion and biogas utilization, in: Bioresource Technology, 100(22), p. 5478-5484.

14. IQAir, 2019, World Air Quality Report 2019.

15. KERR R. A., 2007, Global Warming Is Changing the World, in: Science, 316 (5822), p. 188-190.

16. KROZER Y., 2013, Amsterdam, Cost and benefit of renewable energy in the European Union, in: Renewable Energy, 50, p. 68-73. 
17. KUKLINSKA K., WOLSKA L., NAMIESNIK J., 2015, Air quality policy in the U.S and the EU- a review, in: Atmospheric Pollution Research, 6, p. 129137.

18. MAKARA A., KOWALSKI Z., FELA K., 2017, Zagospodarowanie substancji pofermentacyjnej $\mathrm{W}$ aspekcie bezpieczeństwa ekologicznego, in: Prace Naukowe Akademii im. Jana Dlugosza w Częstochowie, t. V, p. 177-190.

19. MANTLER A., LOGAN A. C., 2015, Natural environments and mental health, in: Advances in Integrative Medicine, 2(1), p. 5-12.

20. McCOLLUM D., ECHEVERRI L. G., RIAHI K., PARKINSON S., 2017, SDG 7 ensure access to affordable, reliable, sustainable and modern energy for all, International Council for Science, Paris, p. 130173.

21. NGUYEN K. Q., 2007, Alternatives to grid extension for rural electrification: Decentralized renewable energy technologies in Vietnam, in: Energy Policy, 35(4), p. 2579-2589.

22. PANWAR N. L., KAUSHIKI S. C., KOTHARI S., 2011, Role of renewable energy sources in environmental protection: A review, in: Renewable and Sustainable Energy Reviews, 15(3), p. 1513-1524.

23. PAWŁOWSKI A., 2006, Lublin, The multidimensional nature of sustainable development, in: Problemy Ekorozwoju/ Problems of Sustainable Development, 1(1), p. 23-32.

24. PEI- DONG Z., GUOMEI J., GANG W., 2007, Contribution to emission reduction of $\mathrm{CO}_{2}$ and $\mathrm{SO}_{2}$ by household biogas construction in rural China, in: $R e$ - newable \& Sustainable Energy Reviews, 11(8), p. 1903-1912.

25. RAM M., BOGDANOV D., AGHAHOSSEINI A., et al., 2017, Berlin, Global Energy System Based on 100\% Renewable Energy, Global Renewable Energy Solutions Showcase, Berlin.

26. Renewables 2019, Global Status Report, REN21, Paris, 2019.

27. RITCHIE H., ROSER M., 2020, Fossil Fuels, ourworldindate.org.

28. SCHWARTZ J., MARCUS A., 1990, Mortality and air pollution in London: A Time Series Analysis, American Journal of Epidemiology, 131(1), p. 185194.

29. SHWOM R., LORENZEN J. A., 2012, Changing household consumption to address climate change: social scientific insights and challenges, in: WIREs Clim Change, 3(5), p. 379-395.

30. SILVA HERRAN D., NAKATA T., 2012, Design of decentralized energy systems for rural electrification in developing countries considering regional disparity, in: Applied Energy, 91(1), p. 130-145.

31. Union of Concerned Scientises, The Hidden Costs of Fossil Fuels, https://www.ucsusa.org/resources/hidden-costs-fossil-fuels (30.08.2016).

32. UNITED NATIONS, Department of Economic and Social Affairs, World Population Prospects 2019, New York.

33. ZAHND A., MCKAY KIMBER H., 2009, Benefits from a renewable energy village electrification system, in: Renewable Energy, 34(2), p. 362-368. 